\title{
3 Research Square \\ Local Knowledge of Utilisation and Threats Patterns of Termites around Pendjari Biosphere Reserve, West - Africa
}

\section{Alain Kpèdékpo Gbeffe ( $\square$ agbeffe@gmail.com )}

Department of Environmental Management, Pan African University, Life and Earth Sciences Institute, University of Ibadan

Thierry D. Houehanou

Unversity of Parakou

Francis A. Adesina

Obafemi Awolowo University

Musiliudeen A. Onilude

Department of Agriculture and Environmental Engineering, Faculty of Technology, University of Ibadan

Marcel B. R. Houinato

Université d'Abomey-Calavi

\section{Research Article}

Keywords: Termites and termite mounds, ethno-entomology, local people traits, sustainable management strategies, threat factors, Pendjari Biosphere Reserve

Posted Date: October 21st, 2021

DOI: https://doi.org/10.21203/rs.3.rs-996890/v1

License: (9) This work is licensed under a Creative Commons Attribution 4.0 International License. Read Full License 


\section{Abstract}

Background: Termites are social insects filling many ecological functions and ecosystem services in tropical ecosystems, and are also used differently for human well-being in several parts of the world. Documenting their use knowledge and associated threats are fundamental for their sustainability. Thus, this study aimed at analysing use knowledge patterns and threat factors of termites within the local communities around Pendjari biosphere reserve (PBR).

Methods: Semi-structured questionnaire was administrated to 151 informants to collect sociodemographic data, use-types and use-categories of termites and their threat factor levels. Fidelity indexes, informant diversity and equitability indexes were computed and compared regarding socio-demographic traits by using a generalized linear models. A pairwise ranking of threat factors followed by series of ordinal logistic regression were performed to assess how informants' socio - demographic traits do influence the perceived effect of threats on termite species. The statistical analyses were done by using $\mathrm{R}$ programming language in Rstudio.

Results: Twenty five use-types of termites and termite mounds were recorded. Ethnicity and gender have significant (P-value $<0.05$ ) influence on the use knowledge pattern of termites, with Gourmantche and Berba the most knowledgeable ethnics of termite and termite mound uses, while women are more knowledgeable than men. Ethnicity and age category have significant (P-value $<0.05)$ influence on perceived threats of agricultural activities and bush fire, while the reported global use values and age category have significant $(P$-value $<0.05)$ influence on the perceived threat of climate change on termites. Old informants are likely to perceive the influence of bushfire, agricultural activities and climate change threats than adult and young informants. Berbas are likely to perceive the influence of agricultural activities and bushfire threats than Gourmantche, Waama and other ethnics.

Conclusion: The findings were therefore supported by gender, age and dynamic of knowledge hypothesis, with gender and ethnicity, the two factors that have significant influence on the uses' diversity and use knowledge pattern of termite and termite mounds. Thus, the sustainable management of termites will be achieved by sensitizing indigenous communities to adopt sustainable agricultural practices associated with the creation of alternative activities to reduce pressure on termites.

\section{Introduction}

Biodiversity has fundamental values to human because of their dependence on it for nutritional, cultural, economic, and environmental/ecological well-being and its mismanagement leads to resource decline and biodiversity crisis [1]. Insects constitute a non-neglected component of biodiversity that deliver a host of ecosystem services fundamental to the survival of humankind [2]. Termites are social insects filling many ecological functions, especially in tropical ecosystems [3,4]. They play an important role in the decomposition of organic matter, soil fertilization, bioturbation and soil formation and vegetation growth and diversity in tropical regions [4-7]. They are important natural resources widely used in traditional 
medicine and also consumed by human populations in several parts of the world (Africa, Asia and America) [8]. Apart from being recognised as important pest and ecological engineer, termite species have therapeutic importance in traditional medicine worldwide [9].

In tropical and sub-tropical ecosystems, termite species are viewed as an important functional group for savannah structure and function, and their mounds have recently been shown to protect against drought by providing refuges for plants and foci for re-vegetation [10]. The benefits and services associated to termites are however under-appreciated and more research is needed for a better capitalization of the importance of termite activity and their diversity in tropical ecosystems because ecosystems services provided by termites are not sufficiently appreciated [5]. Given the importance of traditional knowledge in improving general understanding of insect ecology and biology, policies on the sustainable management and development of edible insect sector must take into account different roles that men and women in one hand, young, adult and old people in other hand play in edible insect management and involve them accordingly [2] for the sustainability of the benefits and goods provided by those insects. Thus, Integrating local people's perception and knowledge in management strategies is important to guarantee local acceptance of the management plans of natural resources and biodiversity conservation [11] in one hand; and the sustainability of ecosystem services delivered by termite species particularly in tropical savannahs in another hand. Additionally, investigations on medicinal uses of animals (termites) and their products, as well as of inorganic materials, should not be neglected and should be considered as an important complementary body of traditional knowledge [12] and taken into account accordingly. Therefore, documenting ecological, uses knowledge and perceptions that local people have on termite species and their threatening factors is an important issue to be addressed. In this perspective a lot of works have been done and addressed the checklist of uses of termite species and their mounds $[7,13,14]$ in savannah ecosystems without emphasizing on the pattern of those uses within the local communities for their better management. The other cultural significance and importance of termite species and their mounds were highlighted, apart from been foods, termite can also be used as feed for poultry or as bait to catch birds and fish [14]. The soldiers, the fungus gardens and the soil of termite mounds are also used for multiple medicinal purposes. Mounds and soil of termites have numerous functions: for geochemical prospecting, making bricks, plastering houses, making pots, and for storage. Termite mound soil is often used as fertilizer, agent for the rehabilitation of degraded lands, for restoring barren soil and for maintaining long-term soil productivity [13]. The mounds can also serve as burying places and are often associated with the spiritual world, especially containing the spirits of ancestors. Termites also play a role as oracle, in superstitious beliefs, in art and literature. The main global impact of termites, outweighing their pest status, is clearly to provide the ecosystem services listed above [14]. From the findings of all above-mentioned studies the question of knowing the pattern of knowledge uses of termites and their mounds is still relevant, due to the fact that studies that have examined the pattern of uses and the local people traits that affect uses and the perceived threats of termites within the local communities are very rare. The few conducted till now just made a checklist of uses regardless their pattern. 
The present study therefore, aimed at analysing the use knowledge and threat factor patterns of termites and their mounds within the local communities around PBR. The specific objectives associated to the study are (i) - to determine the diversity of termites and their mounds uses, (ii) - to assess the variations of range and evenness of uses knowledge among the local communities, (iii) - to examine sociolinguistic and demographic traits that govern local perception of anthropogenic activities, climate change and global use value on termite and termite mounds. In the case of medicinal plant species, age, gender, and dynamics of knowledge hypothesis, various individual socio-cultural and demographic traits such as gender, age, and literacy/formal educational level are all correlated with an individual's level of plant knowledge [15-21]. Age/age categories and gender are the most commonly examined variables [15] with women and older people tending to have greater knowledge of the local medicinal flora $[15,21,22]$. Thus, it had been suggested that (i) - Termite species and their mounds are well known and used differently by local communities around PBR, (ii) - women, older and indigenous people have greater and well distributed use knowledge of termite and termite mounds globally and as well as each use category compared to men, adult and young, and exogenous people respectively; and (iii) agricultural activities and construction uses are the main threats that influence the sustainable uses of termite species and their mounds. The verification of those hypotheses will allow to know the key traits of the local community that should be considered in implementing eventual proposed management strategies of termite species and their mounds to sustain the associated good, services and benefits that could maximize local community's well-being around PBR.

\section{Material And Methods}

\section{Study Area}

The study was carried out in Benin, a West African country located between latitude $6^{\circ} 10^{\prime} \mathrm{N}$ and $12^{\circ} 25^{\prime} \mathrm{N}$ and longitude $0^{\circ} 45^{\prime} \mathrm{E}$ and $3^{\circ} 55^{\prime} \mathrm{E}$, especially within the surrounded villages of Pendjari Biosphere Reserve (PBR). The Biosphere Reserve of Pendjari (PBR) located within Atacora district $\left(10^{\circ} 30^{\prime}-11^{\circ} 30^{\prime} \mathrm{N}, 0^{\circ} 50^{\prime}-\right.$ $2^{\circ} 00^{\prime} \mathrm{E}$ ) (Figure 1) is one of the most important West Africa fauna reserves in term of plants and animals diversity conservation. It covers an area of $4800 \mathrm{~km}^{2}$ and is composed of the National Park of Pendjari $\left(2660 \mathrm{~km}^{2}\right)$, the hunting zone of Pendjari $\left(1750 \mathrm{~km}^{2}\right)$, the hunting zone of Konkombri $\left(251 \mathrm{~km}^{2}\right)$ and the controlled zone (139 $\mathrm{km}^{2}$ ). The reserve was declared a Game Reserve in 1954, and upgraded to a National Park in 1961, and to a Biosphere Reserve in 1986 [23]. PBR is located in the Sudanian zone with one rainy season (April/May to October) and one dry season (November to March/April). The mean annual rainfall is $1000 \mathrm{~mm}$ with $60 \%$ falling between July and September. The mean annual daily temperature is $27^{\circ} \mathrm{C}$. The vegetation is a mosaic of shrubs trees, woodland savannahs and grassland $[24,25]$ regularly burned every year to provide fresh pasture to herbivores that dominate the reserve and increase visibility for touristic and hunting activities. Many small villages bound the Pendjari Biosphere Reserve. The population density in this area is low (38 inhabitants per $\mathrm{km}^{2}$ ) compared with the whole country (87.2 habitants $/ \mathrm{km}^{2}$ ) [26]. Among the bordering local community of the PBR, Berba (65\%), Gourmantche $(23 \%)$ and Waama $(7 \%)$ are the dominant ethnics. The main activity of the local 
population is agriculture and animal herding. Women often exploit non timber forest products like fruits of shea trees among others, leaves of many species and also practice the firewood and charcoal trading.

\section{Sampling of Informants and Data Collection}

A pre-field survey was conducted to determine the maximum sample size that was considered for the main survey. Thus 30 random respondents were selected in six randomly chosen villages among the villages surrounding PBR. Respondents were asked to provide answers to the following questions: "Do you know termite mounds and any services or goods provided by termites to human within the local community?" The proportion $(P)$ of positive answers in each village was used to compute the corresponding sample size $(\mathrm{n})$, while $10 \%$ margin error $(d)$ was considered. The sample size was calculated with the approximation of binomial law to the normal distribution [27].

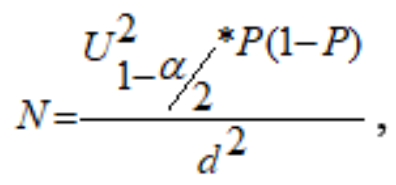

Where $N$ is the size of the sample and $P$ is the proportion of informants who know and use the goods and services related to termites and termite mounds.

A total of 151 informants were chosen by using in each selected village the formulae of [27]. The different use types of termites and their mounds were recorded by using an individual questionnaire. The different categories of uses considered were foods or feeds, construction, medicinal, cultural and energy categories uses. Potential threat factors of natural resources and biodiversity particularly were previously identified from literature and respondents were asked to choose and rank them based on their knowledge and experience. They were asked to use the following defined threat scale level: none (1), low (2), moderate (3) and high (4), to score each of threat factors which are agricultural activities, construction activities, vegetation fire and climate change. The biodata (age, sex and the profession) as well as sociocultural data of the informants (ethnicity, level of study, and seniority in the village) were recorded. The informant's age was grouped into three categories young ( $15 \leq$ age $\leq 30)$, Adult ( $31 \leq$ age $\leq 60)$ and Old (age > 60). For the seniority, the confidence interval IC $(29.95 \pm 3.57)$ was built around the mean and used to define three classes of resident length $(R L)$ within the community. Informants of low ( $R L \leq 26$ years), medium $(26<\mathrm{RL} \leq 34$ years) and high ( $\mathrm{RL}>34$ years) resident length were then defined.

\section{Data Processing and Statistical Analyses}

For each reported use-type, the relative frequency of citation defined as how often a use-report was mentioned was calculated using the fidelity level (FL \%) [28]. The Fidelity level was assessed for both usetypes and use-categories. 


$$
F L=100 \times x / n
$$

Where $x$ is the number of informants who mentioned a specific use or use-category and $n$ is the total number of informants. The fidelity level was compared for different mentioned use-categories for both termites and their mounds using Chi square test.

Use knowledge of termite and termite mounds was measured using the relative use-value (UV) [29,30], a modified version of the use-value method introduced by [31]. This UV allows capturing all the known uses by an individual within and between use-categories $[29,30]$.

$$
U V=\sum_{u c=1}^{n_{i c}} U V u c=\sum_{u c=1}^{n_{L \epsilon}} \sum_{i=1}^{n} U R_{u c, i} / n
$$

Where $U R_{u c, i}$ is the number of use-report mentioned by informant $i$ for a given use-category $u c$. In the dataset, $U R_{u c, i}$ varied from 0 to maximum $\left(U R_{u c, i}\right)=7$, meaning that the maximum number of use-report mentioned by an informant in a use-category was 7. $U V_{u c}$ is the use-value for a given use-category $u c$ which is the mean of $U R_{u c, i}$ for that use-category; $n_{u c}$ is the number of use-categories in the study $\left(n_{u c}=\right.$ 5); $n$ is the number of informants (151).

$U V$ stands as a mean of URuc,i and could vary from 0 to $n \times n_{u c} \times 7$ (in case all informants mentioned all use-categories and that all informants cited a number of use-report equals to 7 in each use-category). Because $U R_{u c, i}$ is a count data, a generalized linear model (GLM) with Poisson error distribution [32] was used to assess variation of $U V$ (response variable) with respect to ethnicity, age category, and gender of informants (predictors). All predictors were categorical with respectively into four (Gourmantche, Berba, Waama and Others), three (Young, Adult and Old), and two (women, men) levels. Likelihood ratio test was used to assess the goodness of fit of the final model. The deviance-based pseudo- $\mathrm{R}^{2}$ was also computed to assess the explanatory quality of the final model.

The informants' diversity index and equitability value (table 1) were used to respectively assess the range and the evenness [33] of use knowledge of termites and termite mounds. In order to identify the key socio-economic factors that affect the use pattern of termites and termite mounds, GLM was implemented on informants' diversity index and equitability value related to termite and the termite mound uses. The indices vary from 0 to 1 [33,34], and their importance was revealed accordingly.

Table 1: Informants' diversity and equitability values used for characterising termite and termite mound uses knowledge pattern among local community 
Informant diversity value (ID) ID = Ux/Ut

Informant equitability value (IE) IE = ID/IDmax
ID, number of uses cited by a given informant (Ux) divided by the number of total uses (Ut)

IE, informant diversity value (ID) divided by this indexes' maximum value (IDmax)
Assess the range of knowledge

Assess the evenness of knowledge

Source: [35]

A pairwise ranking was implemented on the chosen threat factors to determine the factor that most influence use knowledge of termites and termite mounds. The number of possible pairs was calculated using the formulae $\mathrm{N}(\mathrm{N}-1) / 2$, where $\mathrm{N}$ is the number of chosen factors. Scores from each factor were summed up, ranks determined and the factors that received the highest total score were ranked first.

All the statistical analysis was done by using the integrated development environment Rstudio (IDE) of $R$ version 4.0.2 [36].

\section{Results}

\section{Socio-economic Characteristics of the Respondents}

The Table 2 presents the socioeconomic and demographic characteristics of respondents involved in this study. The majority of respondents do not have a formal education (58.60\%) whereas $23.75 \%$ and 15.60 $\%$ have respectively a primary and secondary school level. Their age range is between 15 and 108 years old with an average of 44 years. The young age class ( $15 \leq$ age $\leq 30)$ represents $42.67 \%$, the adults (31 $\leq$ age $\leq 55$ ) and old (age > 55) classes represent respectively $33.12 \%$ and $24.21 \%$ of the respondents. The sample is dominated by Berba ( $52.86 \%$ ) ethnic, followed in this order by Gourmantche $(22.93 \%)$ and Waama $(14.01 \%)$. Their gender is characterized by $64.97 \%$ of male and $35.03 \%$ of female. The majority of the respondents are farmers $(66.24 \%)$ with an average of 29.89 years of seniority in their villages.

Table 2: Socio-economic and demographic characteristics of the informants 
Socio-demographic characteristics

No. of

informants
Percentage

(\%)

Mean \pm SE $\quad p$-value

Level of education

\begin{tabular}{llll} 
No formal education & 90 & 59.60 & \multirow{2}{*}{$2.2 \mathrm{e}-16$} \\
Primary & 36 & 23.84 & 15.23 \\
Secondary & 23 & 1.32 & \\
University & 2 &
\end{tabular}

Age Classes (Years)

Young $(15 \leq$ age $\leq 30)$

57

37.74

Adult (31 $\leq$ age $\leq 55)$

61

40.39

21.85

$43.23 \pm$ 1.40

Old (age > 55)

33

75

49.66

Low

17

59

11.26

39.07

$29.89 \pm$ 1.80

$2.433 \mathrm{e}-12$

High

59

80

52.98

Berba

Gourmantche

35

23.17

13.91

Waama

21

15

9.93

Others

\section{Gender}

Male
Female
Socio-economic profession

\begin{tabular}{lll} 
Farmers & 100 & 66.22 \\
\hline Conservators & 6 & 3.97 \\
\hline Traders & 10 & 6.62 \\
\hline Artisan & 11 & 7.28 \\
\hline Fishermen & 6 & 3.97 \\
Others & 18 & \\
\hline
\end{tabular}


SE stands for "Standard Error"

\section{Diversity Use-types and Use-categories of Termites and Termite Mounds reported by Local Communities}

A total of 26 uses of termite and their mounds were reported by local community around PBR as follows: medicinal (12), Food/Feed (5), Construction and artisanal (4), Cultural and ritual (3) and Energy (2). However, only 23 use reports were found to be significant (Fidelity level $>5 \%$ ) (Figure 2) with five among termite mound uses and 18 among termite uses. Five categories of uses (Foods/Feeds, Medicinal, Construction/Artisanal, Cultural and Energy) were identified. Globally, the categories of food (35\%), construction ( $28 \%$ ) and medicinal $(26 \%)$ uses were the most cited use categories (Table 2 ) by the local communities around PBR. As far as the use-types are concerned, the majority of the respondents cited the utilization of termite for feeding poultry $(100 \%)$, foods for humans $(92.35 \%)$, termite mounds for furnaces $(95.54 \%$ ) and building ( $87.89 \%)$, storage bans $(90.44 \%)$, sites for small mammals hunting $(86.62 \%)$ and for mushroom collection ( $85.35 \%)$. The non-significant reported uses are: the uses of termites for treating fever $(0.64 \%)$, Abscess $(1.91 \%)$, and bones fractures $(3.18 \%)$; the uses of termite mound for the treatment of squirrel bites $(0.64 \%)$.

The Table 3 presents the details of different utilisations cited by the local communities for termites and termite mounds separately. Three main category of utilisation of termite species were mentionned by local communities around PBR, the category of foods (32.70\%), feeds (35.53 \%) and the category of medicinal utilisations $(31.76 \%$ ) with similar fidelity level. Termite mounds were cited for five different use-categories, the categories presented following decreasing order of fidelity level are: construction or artisanal category (36.26\%), medicinal (24.24\%), food (22.97\%), cultural and ritual utilisations (13.77\%) and energy category $(2.74 \%)$ of termite mound uses.

Table 3: Fidelity of termites and their mound use citations following different use-categories 
Fidelity P-value level (FL \%) level)

(Significance

Foods foods for humans (winged termites)

Termites

Foods

$\begin{array}{lll}\text { Feeds } & \text { Feeds for poultry } & \begin{array}{l}35.53 \\ \text { a }\end{array} \\ \text { Medicinal } & \begin{array}{l}\text { Umbilical ache, Fever, Bone fracture, and } \\ \text { abscess }\end{array} & \begin{array}{l}31.76 \\ \text { a }\end{array}\end{array}$

Site for mushroom and honey bees collection, hunting site of small mammals and reptiles medicinal plant collection, squirrel bites,

Medicinal Umbilical dermatitis

b

Termite mounds

Construction

Construction of houses, Construction storage

bans, pots, poultry and animal housing

$\begin{array}{llcl} & & 36.15 & 0.000 \\ \text { Energy } & \begin{array}{l}\text { construction of furnaces, Site of firewood } \\ \text { collection }\end{array} & 2.78 \mathrm{~d} & \end{array}$

Soil amendment, Indicator of soil fertility,

Cultural and (plant, birds, snakes and pangolin)

Shelter from rain and habitat for other species

ritual

11.97

C

Use-categories followed by the same letter within each variable (termite and termite mound) are statistically similar.

Factors affecting reported Use-values of Termites and Termite Mounds around Pendjari Biosphere Reserve 
There was a highly significant $(p<0.01)$ relationship between overall knowledge of termite species and termite mound uses, and ethnicity and gender (Table 4). The relationship is not significant between ethnicity and termite mound uses, whereas it is lightly $(p=0.052)$ between termite mound uses and gender.

Table 4: Predictors in the best Poisson models showing relationship between socio-demographic attributes with use - values (overall use-value, termite mound use and termites' use-value).

\begin{tabular}{|c|c|c|c|c|c|c|c|c|c|}
\hline \multirow[t]{2}{*}{ Predictors } & \multicolumn{3}{|c|}{ Overall use-value } & \multicolumn{3}{|c|}{ TM use - value } & \multicolumn{3}{|c|}{ Termite use - value } \\
\hline & df & Dev. & $\begin{array}{l}\mathrm{p}- \\
\text { value }\end{array}$ & df & Dev. & $\begin{array}{l}\mathrm{p}- \\
\text { value }\end{array}$ & df & Dev. & $\begin{array}{l}\mathrm{p}- \\
\text { value }\end{array}$ \\
\hline Ethnicity (E) & 3 & 14.42 & 0.0023 & 3 & 5.501 & 0.138 & 3 & 15.90 & 0.0011 \\
\hline Gender (G) & 1 & 9.87 & 0.0016 & 1 & 3.773 & 0.052 & 1 & 7.637 & 0.0057 \\
\hline $\begin{array}{l}\text { Goodness of } \\
\text { fit test }\end{array}$ & 146 & 118 & 0.4575 & 146 & 127.7 & 0.4206 & 143 & 42.38 & 0.3325 \\
\hline R-square (\%) & \multicolumn{3}{|c|}{24.34} & \multicolumn{3}{|l|}{9.98} & \multicolumn{2}{|c|}{40.80} & \\
\hline
\end{tabular}

df: degree of freedom, Dev: deviation, p-value: associated probability to the analysis, TM: termite mound Considering overall uses of termite and termite mounds, Gourmantche informants (14.11 \pm 0.34 ) reported more uses than Berba (12.46 \pm 0.39$)$, Waama (11.54 \pm 0.57$)$ and other (10.63 \pm 0.85$)$ ethnics. The same order was obtained for the uses of termites where Gourmantche informants $(3.96 \pm 0.17)$ reported more uses than Berba (3.23 \pm 0.13$)$, Waama $(2.45 \pm 0.17)$ and other $(2.00 \pm 0.22)$ sociolinguistic groups, while they have similar reported uses of termite mounds. Women $(3.58 \pm 0.17)$ reported more uses of termites than men $(2.74 \pm 0.09)$. The same trend of result was obtained for women where $13.57 \pm 0.36$ and $9.98 \pm$ 0.30 uses were reported respectively for overall uses and termite mound uses, $11.78 \pm 0.35$ and $9.04 \pm$ 0.30 uses reported by men for overall uses and termite mound uses respectively. It is obvious from those results that Gourmantche and Berba were globally more knowledgeable of termite and termite mounds uses than Waama and other ethnics.

Those abovementioned uses greatly varied across use-categories in relation to gender and ethnicity (Figure 3). Thus, women have in average greater knowledge of medicinal uses of termites (Figure 3a), termite mound (Figure 3b) and overall uses (Figure 3c) than men while the knowledge of other uses were similar. Meanwhile, it is worthy to highlight that food and construction uses were higher for both gender compared to cultural and energy uses of termites, termite mound and overall uses. As far as ethnicity is concerned, Gourmantche and Berba reported higher uses of medicinal and food categories of termite uses compared to Waama and other ethnics (Figure 3d). Medicinal, Food and construction use-categories of termites mound and overall uses were the highest reported by Gourmantche ethnic followed by Berba and Waama in decreasing order of reported uses (Figure $3 e \& f$ ). Women are more knowledgeable of 
medicinal uses than men while Gourmantche and Berba are richer of medicinal and food uses of termite and termite mound.

\section{Variations of Use Knowledge Range and Evenness of Termite and Termite Mound following Socio- demographic Characteristics}

Gender has significant ( $p$-value $<0.05$ ) influence on informant diversity index (Figure 4a) and equitability index (Figure $4 \mathrm{~b}$ ) of termites, termite mounds and the overall uses. Female diversity indexes are significantly higher than male ones for termites (female: $0.512 \pm 0.024$ versus male: $0.392 \pm 0.013$ ), termite mounds (female: $0.525 \pm 0.016$ versus male: $0.476 \pm 0.016$ ) and the overall uses (female: $0.522 \pm$ 0.014 versus male: $0.453 \pm 0.013$ ). The same trend were observed for informants equitability index for termites (female: $0.597 \pm 0.028$ versus male: $0.456 \pm 0.016$ ), termite mounds (female: $0.665 \pm 0.02$ versus male: $0.603 \pm 0.02$ ) and overall uses (female: $0.714 \pm 0.019$ versus male: $0.620 \pm 0.018$ ). Women (ID > 0.5 ) are more knowledgeable of termites, termite mound and overall uses than men (ID $<0.5)$, but those knowledge are well distributed among the two gender except termite uses where the knowledge were not well distributed $(\mathrm{IE}<0.5)$ among men.

Ethnicity has significant influence on informant diversity index (Figure 4c) and equitability index (Figure $4 d$ ) of termites and the overall uses, while it has no significant influence on informant diversity and equitability indexes. Berba (ID = 0.485 \pm 0.017 , IE $=0.615 \pm 0.021)$, Gourmantche $(\mathrm{ID}=0.547 \pm 0.02$, IE $=$ $0.693 \pm 0.025)$, Waama (ID = $0.478 \pm 0.027, \mathrm{IE}=0.606 \pm 0.035)$ and others (ID $=0.455 \pm 0.04, \mathrm{IE}=0.576 \pm$ $0.05)$ ethnics have almost similar informant diversity and equitability indexes. Therefore, uses knowledge of termite mound are relatively high and well distributed among all sociolinguistic groups. In contrary to the obtained results for ethnics related to termite mound use knowledge, Gourmantche ethnic has the highest ID and IE for termite (ID $=0.528 \pm 0.024$, IE $=0.616 \pm 0.028)$ and overall $(I D=0.543 \pm 0.013, I E=$ $0.741 \pm 0.018$ ) use knowledge respectively. It is followed in decreasing order of ID and IE by Berba, Waama and other ethnics that are characterised by IDs and IEs both less than 0.5. Gourmantche ethnic is more knowledgeable of termite and overall uses which knowledge is well distributed among them compared to Berba, Waama and others (Fulani, Dendi, Natimba, Boulba and Hausa) where the use knowledge of termites and overall uses are partially distributed.

Age classes have no significant ( $p$-value $>0.05$ ) effects on the informant's both diversity index (Figure 4e) and equitability index (Figure $4 \mathrm{f}$ ) of knowledge uses of termites, termite mounds and the overall uses knowledge. All young, adult and old people have little knowledge $(I D<0.5)$ on uses of termites, termite mounds and overall uses. This little knowledge is well distributed (IE $>0.5$ ) among young, adult and old people, except termite specimen use knowledge that is partially distributed $(\mathrm{IE}<0.5)$ among adults and old people.

xxxFigure 4: Influence of sociocultural factors on the use knowledge pattern of termites and their mounds around Pendjari Biosphere Reserve 
Important and variation of threat factors on termites and termite mounds around Pendjari Biosphere Reserve

\section{Major threat factors of termites and termite mounds}

Four major factors were selected for their significant threat on termites and termite mounds around Pendjari biosphere reserve according to local communities' perception. Agricultural activities characterised by slash and burning were ranked the top among the mentioned factors (Figure 5) that affect termite, termite mounds and the associated good and services. They were followed in decreasing order by construction based on exploitation of dead termite mound, bush fires which occur periodically each year and climate change as a global concern.

\section{Influence of socio - linguistic and demographic traits on threat factors of termites and termite mounds}

The perceived threats of agriculture activities, bushfire on termite and termite mounds are influenced by informants' ethnicity and age category while the perceived threats of climate change are influenced by informant's age category and the reported global use values of termite and termite mounds (Table 5). Concerning the perceived threats of climate change, old and young informants are likely to perceive climate change threats on termites and termite mounds 0.133 and 0.697 times less that of adult informants respectively with all other variable constant. For every one unite increasing of termite and termite mounds global use value, the informants' ability of perceiving climate change threats on termites and termite mounds is multiplied by 1.176 (i.e., increases of $17.6 \%$ ) holding all others predictors constant.

As the perceived threats of bushfire are concerned, old informants are likely to perceive bushfire threats 4.937 times that of adults while young informants are likely to perceive vegetation fire threats 0.910 times less that of adults. Gourmantche, Waama and other ethnics are likely to perceive bushfire threats 0.198 times, 0.271 times and 0.238 times less that of Berba ethnic respectively.

Concerning the perceived threats of agricultural activities, old informants are likely to perceive agricultural activities threats 41.172 times that of adults while young informants are likely to perceive agricultural activities threats 0.697 times less that of adults. Gourmantche, Waama and other ethnics are likely to perceive agricultural activity threats 0.191 times, 0.050 times and 0.038 times less that of Berba ethnics respectively.

Table 5: Relationship between informants' socio-linguistic traits and importance of perceived threats on termites and termite mounds 
Variables

Coef SE

$P$-value $\quad O R$

$95 \% \mathrm{Cl}$ of OR

Perceived influence of Climate Change

\begin{tabular}{llllll} 
Age class-Old & -2.015 & 0.622 & 0.001 & 0.133 & $0.035-0.424$ \\
\hline Age class-Young & -0.360 & 0.527 & 0.494 & 0.697 & $0.243-1.948$ \\
\hline Gender-Male & -0.640 & 0.461 & 0.165 & 0.527 & $0.210-1.294$ \\
\hline Ethnicity-Gourmantche & 0.447 & 0.581 & 0.442 & 1.563 & $0.498-4.947$ \\
\hline Ethnicity-Waama & -0.177 & 0.653 & 0.786 & 0.837 & $0.222-2.963$ \\
\hline Ethnicity-Others & 0.202 & 0.692 & 0.770 & 1.224 & $0.306-4.759$ \\
\hline Global Use-value & 0.162 & 0.078 & 0.039 & 1.176 & $1.012-1.381$ \\
\hline Intercept 1 & 1.316 & 1.151 & 0.253 & - & - \\
\hline Intercept 2 & 3.817 & 1.234 & 0.002 & - & -
\end{tabular}

Perceived influence of Vegetation Fire

\begin{tabular}{llllll} 
Age class-Old & 1.596 & 0.539 & 0.003 & 4.937 & $1.763-14.8$ \\
\hline Age class-Young & -0.093 & 0.509 & 0.854 & 0.910 & $0.333-2.479$ \\
\hline Gender-Male & -0.105 & 0.435 & 0.809 & 0.899 & $0.381-2.114$ \\
\hline Ethnicity-Gourmantche & -1.618 & 0.601 & 0.007 & 0.198 & $0.058-0.631$ \\
\hline Ethnicity-Waama & -1.304 & 0.573 & 0.033 & 0.271 & $0.085-0.823$ \\
\hline Ethnicity-Others & -1.433 & 0.673 & 0.023 & 0.238 & $0.061-0.882$ \\
\hline Global Use-value & 0.016 & 0.070 & 0.817 & 1.016 & $0.885-1.167$ \\
\hline Intercept 1 & -1.519 & 1.074 & 0.157 & - & - \\
\hline Intercept 2 & 0.984 & 1.067 & 0.356 & - & - \\
\hline Intercept 3 & 61.900 & 1.067 & 0.000 & - & -
\end{tabular}

Perceived influence of Agricultural Activities

\begin{tabular}{llllll} 
Age class-Old & 3.717 & 0.827 & 0.000 & 41.172 & $9.311-250.91$ \\
\hline Age class-Young & -0.359 & 0.535 & 0.501 & 0.697 & $0.242-2.00$ \\
\hline Gender-Male & 0.133 & 0.478 & 0.781 & 1.142 & $0.444-2.930$ \\
\hline Ethnicity-Gourmantche & -1654 & 0.631 & 0.009 & 0.191 & $0.052-0.639$ \\
\hline Ethnicity-Waama & -2.982 & 0.756 & 0.000 & 0.050 & $0.007-0.177$ \\
\hline Ethnicity-Others & -3.248 & 0.809 & 0.000 & 0.038 & $0.104-0.208$
\end{tabular}




\begin{tabular}{llllll} 
Global Use-value & -0.074 & 0.078 & 0.346 & 0.928 & $0.792-1.081$ \\
\hline Intercept 1 & -5.763 & 1.376 & 0.000 & - & - \\
\hline Intercept 2 & -2.258 & 1.217 & 0.064 & - & - \\
\hline Intercept 3 & -0.879 & 1.189 & 0.460 & - & -
\end{tabular}

Coef: regression coefficient, SE: Standard error, OR: Odd ratio, p-value = probability of significant level and Cl: confident interval of odd ratio

\section{Discussion}

\section{Diversity of reported use types and use-categories of termite and termite mounds by local community}

Food $(76.26 \%)$ and medicinal $(23.73 \%)$ use-categories were the most cited utilization of termite species mentioned by the local community. Termites were mentioned to be used as food (Figure $6 \mathrm{~g}$ ) by humans especially the winged of Macrotermes genus or as feedings of poultry in general. This result is due to the fact that termites are widely consumed by people from all over the world because they provide the relevant amount of organic nutrients [37]. The utilization of Termites mainly Macrotermes as food, was also mentioned in some other tropical countries like Nigeria [38], Kenya [39], South Africa [40], and India [41]. In the villages surrounding PBR, the winged and roasted termites are the direct consumption form mentioned by informants. This was also observed in Nigeria [42] and in northern part of republic of Benin where winged termites are roasted and relished as a snack by people living the traditional lifestyle [4]. Termites especially Microtermes spp reported to be used as feeds for poultry (Figure $6 \mathrm{j} \& \mathrm{k}$ ) in this study area, was not only reported in West Africa, but also in Burundi, Cameroon, Central African Republic, Congo, Madagascar and Tanzania [14]. The individuals of termite species, alone or in combination with their mounds in some cases, were also used to treat Umbilical ache, Fever, Bone fracture, and abscess in the study area which made medicinal use-category the second most cited use-category. These are in contrary with those of [4] who recorded no utilization of termites in traditional medicine within the adjacent phytodistricts to the present study area (Atacora phytodistrict). From the above-mentioned treated diseases using termites and the fact that medicinal uses of termites were also highlighted in many other part of the world, the findings are supported by the evidence of antibiotic [43], antimicrobial $[44,45]$, antifungal and antibacterial [46] properties of some termite species.

Apart from the direct uses of termite species, the respondents recognized the importance and cited some uses of termite mounds. The category of construction uses of termite mounds was the most cited one. Thus, termite mounds especially the one of Macrotermes were used as construction or building material of furnaces, houses (Figure $6 \mathrm{e}, \mathrm{f}, \mathrm{h} \& \mathrm{i}$ ) storage bans pots, and housing for animal in general and poultry particularly. This remarks corroborated the one of Van Huis [14] who noticed that soil from deserted termite mounds is used for house construction in many parts of Africa like, in Togo termite mound soil is used to make furnaces in Akebu, Cotocoli, Ewe and Kabye communities. It is used as a kind of plaster for huts and for granaries to make the walls more resistant and smooth in Burkina Faso, Chad, Mali, 
Mozambique, Niger, Tanzania, Zambia and Zimbabwe. Likewise, the floor is done this way (Burkina Faso), and mixed with cow dung in order to make it really smooth (Mozambique, Sudan, Zambia, Zimbabwe). Medicinal and indirect food uses of termite mounds have also been mentioned by the local community of PBR. Thus, the intake of termite mound soil mixed with cow milk to treat the following health issues: the deficiency of iron in human blood, mumps, squirrel biting and umbilical dermatitis. The termite mounds are recognized as site for medicinal plant organs collection of some particular plant species (Figure $6 \mathrm{a}, \mathrm{b}$ ), site for firewood collection (Figure 6c) and habitat for wildlife (Figure 6d).

\section{Distribution of Use Knowledge pattern among local community and threats of termite and termite mounds around Pendjari biosphere Reserve}

Traditional knowledge analysis of termites, termite mounds and their global uses revealed that the information on use values of termites, termite mounds and their global uses were mainly influenced by the sociolinguistic groups and the gender. Despite the fact this study is related to an insect (termites) finding aligned with gender, age and dynamic of knowledge hypothesis which suggests that various individual socio-cultural/sociolinguistic and demographic traits such as gender, age, and literacy/formal educational level are correlated with an individual's level of plant knowledge [15-21]. Concerning the gender, the findings showed that Women are globally more knowledgeable of uses of termite, termite mounds and overall uses than men, and especially medicinal uses of termite, termite mounds. In many traditional societies, women are the primary healthcare providers in their households, so it is understandable their medicinal plant knowledge is greater than that of men [15], more they are the one in association with the kids in charge of collection edible part of plants and insects, among many other, for food purpose. These are in concordance with the finding of some previous studies on medicinal plant species $[47,48]$ in general, and other multipurpose plant species such as Borassus aethiopum [30], Sclerocarya birrea [49], Tamarindus indica [50] and Adansonia digitata where women had more uses knowledge than men. This is in contradiction with the findings on Cola nitida [35] where men had more uses knowledge than women. The authors justified by the fact that $C$. nitida is widely used for rituals often leaded by men traditional healer "vodounon". Those knowledge are well distributed among the two gender except termite uses where the knowledge were not well distributed among men. In another words the knowledge richness of uses of termite uses among men were detained by very few individuals.

For Ethnicity attributes, Gourmantche and Berba were more knowledgeable of termite and termite mounds uses due to the richness of their knowledge of medicinal and food uses of termite and termite mound in opposition to Waama and other sociolinguistic groups. This can be differently justified for Gourmantche and Berba sociolinguistic groups. Gourmantche rely only on natural resources and agro pastoral activities because they are enclosed between PBR and the Atacora mountain chain, and were inside the PBR before it was classified as game reserve in 1954, before it had been upgraded to Biosphere Reserve in 1986 [24]. More, they are located at almost $40 \mathrm{~km}$ from the main road "Route Inter Etat 2 (RIE2)" and don't have easy access to primary healthcare. This is in support with the findings of Weckmuller et al [48] who stipulated that communities that are more physically isolated, inaccessible by road, and without easy access to primary health care, have a significantly higher use knowledge than 
those communities with a road and easy, free access to a Western doctor. The second group is the dominant sociolinguistic group of the region and located along the main road, thus they are in constant contact with other sociolinguistic group of the whole country and may gain a lot from this contact. The richness of knowledge on termites and termite mounds is similar for the considered age classes (young, adult and old), this is in contradiction with gender dynamic hypothesis of medicinal plant use knowledge which stipulated that older people have had much more experience with medicinal plant species over the course of their lives [51].

\section{Threatening factors of termites and termite mounds around Pendjari Biosphere Reserve}

Agricultural activities have been pointed out as the factor that affect most termites and termite mounds for the sustainable uses of the associated benefits, good and services. This was in concordance with the direct observations made on ground in one hand and to the findings of some authors in other hands. Firstly, agricultural activities in the study area are characterized by extensive slash and burning which require a lot of mass land to sustain an increasing population. This confirm the finding of Ackerman et al [52] that concluded termite species richness, abundance, and function often decline where forests are replaced by agricultural ecosystems (Agriculture, pasture and agroforestry systems). The agricultural activities are characterised by a heavy use of chemical mainly for the production of cotton in the area, and for yield improvement associated with the perception of pest status of termite species. This use of chemical is very detrimental to soil biodiversity in general and termites in particular when associated with the destruction of the termite mounds within agricultural lands because of the geographical position and status of the reserve don't allow the extension of the agricultural land by clearing natural vegetation [53] and was really stressed by riverine population during discussion.

Construction based on the use of termitaria soils because of its high clay content was also mentioned as major threat. This is the major construction material in so many villages around PBR. The promotion of construction of Voûte Nubienne (houses) based only on termite mound soils; which houses are more comfortable and adopted for the semi-arid and arid climates. Vegetation fire is a tool generally use in the area for management purpose. It is used to clear vegetation around the buildings to avoid incidence due to accidental fire and with the PA for hunting and tourism activities. Climate change in the other hands is a global concern and needs holistic actions to mitigate its effects on conservation of termites and their associated benefits, good and services.

Ethnicity and age category are the two factors that influence the perceived threats of agricultural activities and bushfire on termite and termite mound. Berba are likely to perceive agricultural activities and bushfire threats more than that of Gourmantche, Waama ethnics and others. Old informants followed by adults are likely to perceive bushfire threats more than that of young's one. As threats of climate change are concerned, the perceived threats of climate change are influenced by informant's age category and the reported global use values of termite and termite mounds. Thus, adults are likely to perceive climate change threats more than that of old and young informants in this order; and one unite increasing of termite and termite mounds' global use value, the informants' ability of perceiving climate 
change threats on termites and termite mounds increases of $17.6 \%$ holding all others predictors constant. These findings are in concordance with those of Norman et al. [54] who stated that age acts to increase an Individual's ability to perceive the threat. In another words, ability to perceive threats is accumulated along the life span because the perception is experience dependent [55]. It can also be justified by the fact that the extensive growth of agriculture is associated with increasing threats to biodiversity at all-time scales [56] including termites and all the associated goods and services.

\section{Conclusion}

The present study showed that the local people around PBR have different knowledge and use differently termites and (termite mounds). Termite species have food, feed and medicinal uses within the community, whereas their mounds have food, medicinal, construction, energy and cultural uses. Regardless the age, the sociolinguistic groups (ethnicity) and gender were identified as the traits that influence the utilisation and use knowledge pattern of termites and their mounds around PBR. Gourmantche and Berba sociolinguistic groups were identified as the most knowledgeable of termite and termite mound uses, which knowledge is well distributed among them compared to the others, while women are more knowledgeable than men, and this knowledge is well distributed among women. Ethnicity and age category are the two factors that influence the perceived threats of agricultural activities and bushfire on termite and termite mound while the perceived threats of climate change are influenced by informant's age category and the reported global use-values of termite and termite mounds.

Thus, in short terms, management action should be oriented towards the adults through sensitization on the importance of conserving termite species and their various habitats in order to make their associated benefits, good and services more available for the people around PBR. Environmental education on the importance of termite species and their associated benefits, good and services should be the key in the primary and secondary schools of the riverine villages around PBR. The promotion of trading roasted winged termites can also be an alternative diversification of household sources of income within the local community. Further studies are needed to analyse market value and the feasibility of trading roasted winged termites and access the proportion of living macrotermes mounds by including the flying distance of alates, the possible harvested quantity and their spatio-temporal variability. In long term, firstly implementing researches that can really define the quantity of termite mound soil that should be collected either on living or dead mounds in one hand and quantifying the real impact of each threatening factors on termites species biodiversity in relation to their importance in the ecosystems. Secondly, conceive a hand book (lexicon) on identification, recognition of PBR termite species and their uses in order to make those knowledge more available and transmissible from one generation to another.

\section{Declarations}

Acknowledgements 
The authors are most grateful to Human Resources Sciences and Technology department of African Union Commission (AUC) for funding this research through Ph.D. scholarship to AKG in 2016/2017 at Pan African University, Life and Earth Sciences Institute hosted by University of Ibadan. We are also grateful to staff of African Park Network and our local guides Blaise N'Ouéni and Elisé Djato during the field work. Finally, we are grateful to the editor and anonymous reviewers for their constructive comments that helped to improve the manuscript.

\section{Availability of data and materials}

The dataset used and/or analysed as well as the r-scripts used in the current study are fully available from the corresponding author on a reasonable request.

\section{Authors 'information}

Department of Environmental Management, Pan African University Life and Earth Sciences Institute, University of Ibadan (PAULESI/UI), Oyo State, Federal Republic of Nigeria

Alain Kpèdékpo Gbeffe (AKG), Francis A. Adesina (FAA) \& Onilude A. Musiliudeen (MAO)

Department of Agriculture and Environmental Engineering, Faculty of Technology; University of Ibadan, Oyo State, Federal Republic of Nigeria

Onilude A. Musiliudeen (MAO)

Laboratory of Applied Ecology, Faculty of Agronomic Sciences, University of Abomey - Calavi (LEA/FSA/UAC), Cotonou, Republic of Benin

Alain Kpèdékpo Gbeffe (AKG), Thierry D. Houehanou (TDH) \& Marcel B. R. Houinato (MBRH)

Laboratory of Ecology, Botany and Plant Biology, Faculty of Agronomy, University of Parakou (FA/UP), Parakou, Republic of Benin

Thierry D. Houehanou (TDH)

Department of geography, Faculty of Social Sciences, Obafemi Awolowo University, Osun State, Federal Republic of Nigeria

Francis A. Adesina (FAA)

\section{Authors 'contribution}

AKG conceived the research work with the guidance of TDH, FAA, MAO and MBRH. AKG collected and processed the data. AKG drafted the manuscript with the contribution of TDH and MBRH. All authors read and approved the final manuscript. 


\section{Corresponding author}

Correspondence to Alain Kpèdékpo Gbeffe.

\section{Ethics declarations}

\section{Ethics approval and consent to participate}

Individual consent to participate in the study was obtained prior to implementing the questionnaire. Only individuals that consented to participate in the study were considered.

\section{Consent for publication}

Written informed consent for publication was obtained for photographs related to individual persons in Figs.6. A copy of each consent form is available for review by the Editor of this journal.

\section{Conflict of interests}

The authors declare that there is no competing interests

\section{Funding}

This study was funded as a full PhD scholarship by the Human Resources, Sciences and Technology Department of African Union Commission (AUC).

\section{Bibliographic References}

1. Gandile AU, Tessema SM, Nake FM. Biodiversity conservation using the indigenous knowledge system: The priority agenda in the case of Zeyse, Zergula and Ganta communities in Gamo Gofa Zone (Southern Ethiopia ). International Journal of Biodiversity and Conservation. 2017;9:167-82.

2. FAO. Edible insects Future: prospects for food and feed security. 2013.

3. Sane H, Samb T, Ndiaye AB, Ba CT. Etude de la diversité des termites (Isoptera) dans quelques localités de la région de Kolda (Haute Casamance, Sénégal). 2016;12:263-80.

4. Loko LEY, Orobiyi A, Agre P, Dansi A, Tamò M, Roisin Y. Farmers' perception of termites in agriculture production and their indigenous utilization in Northwest Benin. Journal of Ethnobiology and Ethnomedicine. 2017;13:1-12.

5. Jouquet P, Traoré S, Choosai C, Hartmann C, Bignell D. Influence of termites on ecosystem functioning. Ecosystem services provided by termites. European Journal of Soil Biology. Elsevier Masson SAS; 2011;47:215-22. 
6. Jouquet P, Guilleux N, Caner L, Chintakunta S, Ameline M, Shanbhag RR. Influence of soil pedological properties on termite mound stability. Geoderma. 2016;262:45-51.

7. Dossou-Yovo HO, Vodouhe FG, Sinsin B. Assessment of the medicinal uses of plant species found on termitaria in the Pendjari biosphere reserve in Benin. Journal of Medicinal Plant Research. 2014;8:36877 .

8. Figueirêdo RECR de, Vasconcellos A, Policarpo IS, Alves RRN. Edible and medicinal termites: a global overview. Journal of Ethnobiology and Ethnomedicine. 2015;11:1-7.

9. Choudhury S, Sankar Das K, Nonglait LKC. Ecological and Medicinal Importance of Termite Fauna. The NEHU Journal. 2017;XV:79-87.

10. Joseph SG, Eymour CL, Coetzee BWT, Ndlovu M, De La Torre A, Suttle R, et al. Microclimates mitigate against hot temperatures in dryland ecosystems: Termite mounds as an example. Ecosphere. 2016;7:111 .

11. Houehanou TD, Assogbadjo AE, Kakaï RG, Houinato M, Sinsin B. Valuation of local preferred uses and traditional ecological knowledge in relation to three multipurpose tree species in Benin (West Africa). Forest Policy and Economics. Elsevier B.V.; 2011;13:554-62.

12. Vijayakumar S, Morvin Yabesh JE, Prabhu S, Ayyanar M, Damodaran R. Ethnozoological study of animals used by traditional healers in Silent Valley of Kerala, India. Journal of Ethnopharmacology. 2015;162:296-305.

13. Kaiser D, Lepage M, Konaté S, Linsenmair KE. Ecosystem services of termites (Blattoidea: Termitoidae) in the traditional soil restoration and cropping system Zaï in northern Burkina Faso (West Africa). Agriculture, Ecosystems \& Environment. 2017;236:198-211.

14. van Huis A. Cultural significance of termites in sub-Saharan Africa. Journal of Ethnobiology and Ethnomedicine. 2017;13:1-12.

15. Albuquerque UP, Soldati GT, Sieber SS, Ramos MA, De Sá JC, De Souza LC. The use of plants in themedical system of the Fulni-ô people NE Brazil. A perspective on age and gender. Journal of Ethnopharmacology. 2011;133:866-73.

16. Gaoue OG, Coe MA, Bond M, Hart G, Seyler BC, McMillen H. Theories and Major Hypotheses in Ethnobotany. Economic Botany. 2017;71:269-87.

17. Hanazaki N, Herbst DF, Marques SM, Vandebroek I. Evidence of the shifting baseline syndrome in ethnobotanical research. Journal of Ethnobiology and Ethnomedicine. 2013;9.

18. McCarter J, Gavin MC. Assessing variation and diversity of ethnomedical knowledge: A case study from Malekula Island, Vanuatu. Economic Botany. 2015;69:251-61. 
19. Souto A, Ticktin T. Understanding interrelationships among predictors (age, gender, and origin) of local ecological knowledge. Economic Botany. 2012;66:149-64.

20. Voeks RA. Are women reservoirs of traditional plant knowledge? Gender, ethnobotany and globalization in northeast Brazil. Singapore Journal of Tropical Geography. 2007;28:7-20.

21. Voeks RA, Leony A. Forgetting the forest: Assessing medicinal plant erosion in eastern Brazil. Economic Botany. 2004;58:94-106.

22. Torres-Avilez W, de Medeiros PM, Albuquerque UP. Effect of Gender on the Knowledge of Medicinal Plants: Systematic Review and Meta-Analysis. Evidence-Based Complementary and Alternative Medicine. 2016;2016:1-14.

23. IUCN. Evaluation of Nominations of Natural and Mixed Properties to the World Heritage List. Gland/Switzerland; 2002.

24. Assédé EPS, Adomou AC, Sinsin B. Magnoliophyta, Biosphere Reserve of Pendjari, Atacora province, Benin. Check List. 2012;8:642.

25. Gbeffe AK, Houehanou TD, Habiyaremye M, Assede ESP, Yaoitcha AS, Janssens de Bisthoven L, et al. Effects of termite mounds on composition, functional types and traits of plant communities in Pendjari Biosphere Reserve (Benin, West Africa). African Journal of Ecology. 2017;55:580-91.

26. INSAE. Synthèse des Analyses sur l'Etat et la Structure de la Population. Cotonou, Bénin: Institut National de la Statistique et de l'Analyse Economique; 2017.

27. Dagnelie P. Statistiques théoriques et appliquées. De Boeck e. Brussels; 1998.

28. Friedman J, Yaniv Z, Dafni A, Palewitch D. A preliminary classification of the healing potential of medicinal plants, based on a rational analysis of an ethnopharmacological field survey among Bedouins in the Negev Desert, Israel. Journal of Ethnopharmacology. 1986;16:275-87.

29. Etongo D, Djenontin INS, Kanninen M, Glover EK. Assessing use-values and relative importance of trees for livelihood values and their potentials for environmental protection in Southern Burkina Faso. Environ Dev Sustain. 2017;19:1141-66.

30. Salako KV, Moreira F, Gbedomon RC, Tovissodé F, Assogbadjo AE, Glèlè Kakaï RL. Traditional knowledge and cultural importance of Borassus aethiopum Mart. in Benin: interacting effects of sociodemographic attributes and multi-scale abundance. Journal of Ethnobiology and Ethnomedicine. 2018;14:36.

31. Phillips O, Gentry AH. The useful plants of Tambopata, Peru: I. Statistical hypotheses tests with a new quantitative technique. Econ Bot. 1993;47:15-32. 
32. Zuur AF, Leno EN, Walker NJ, Saveliev AA, Smith GM. Zero-truncated and zero-inflated models for count data. Mixed effects models and extensions in ecology with R. New York: Springer; 2009.

33. Byg A, Baslev H. Diversity and use of palms in Zahamena, eastern Madagascar. Biodiversity \& Conservation. 2001;10:951-70.

34. Monteiro JM, Albuquerque UP, Lins-Neto EMF, Araújo EL, Amorim ELC. Use patterns and knowledge of medicinal species among two rural communities in Brazil's semiarid northeastern region. Journal of Ethnopharmacology. 2006;105:173-86.

35. Savi KM, Noumonvi R, Chadaré FJ, Dainou K, Salako KV, Idohou R, et al. Synergy between traditional knowledge of use and tree population structure for sustainability of Cola nitida (Vent.) Schott. \& Endl in Benin (West Africa). Environment, Development and Sustainability. 2018;

36. R Core Team. R: A language and environment for statistical computing. [Internet]. Vienna, Austria; 2020. Available from: https://www.R-project.org/

37. Figueirêdo RECR de, Vasconcellos A, Policarpo IS, Alves RRN. Edible and medicinal termites: a global overview. Journal of Ethnobiology and Ethnomedicine. 2015;11:29.

38. Fasoranti JO, Ajiboye DO. Some Edible Insects of Kwara State, Nigeria. American Entomologist. 1993;2:112-6.

39. Ayieko MA, Oriamo V, Nyambuga IA. Processed products of termites and lake flies: improving entomophagy for food security within the Lake Victoria region. African Journal of Food Agriculture and Nutrient Development. 2010;10:2085-98.

40. Lesnik JJ. Termites in the hominin diet: A meta-analysis of termite genera, species and castes as a dietary supplement for South African robust australopithecines. Journal of Human Evolution. 2014;71:94-104.

41. Wilsanand V. Utilization of Termite, Odontotermes formosanus by Tribes of South India in Medicine and Food. Explorer. 2004;4.

42. Adepoju OT, Omotayo OA. Nutrient composition and potential contribution of winged termites (Macrotermes belicosus Smeathman) to micronutrient intake of consumers in Nigeria. British Journal of Applied Science and Technology. 2014;4:149-58.

43. Coutinho DMH, Vasconcellos A, Lima AM, Almeida-Filho G, Alves RRN. Termite usage associated with antibiotic therapy: enhancement of aminoglycoside antibiotic activity by natural products of Nasutitermes corniger (Motschulsky 1855). Journal of Ethnobiology and Ethnomedicine. 2009;9:1-4.

44. Arango RA, Carlson CM, Currie CR, McDonald BR, Book AJ, Green III F, et al. Antimicrobial activity of Actinobacteria Isolated From the Gut of Subterranean Termites. Environmental Entomology. 
45. Da Silva P, Jouvensal L, Lamberty M, Philippe B, Caille A, Vovelle F. Solution Structure of termicin, an antimicrobial peptide from the termite Pseudacanthotermes spiniger. Protein Science. 2003;12:438-46.

46. Zeng Y, Ping Hu X, Suh S-J. Characterization of Antibacterial Activities of Eastern Subterranean Termite, Reticulitermes flavipes, against Human Pathogens. PLoS ONE. 2016;11:e0162249.

47. Beltran-Rodriguez L, Ortiz-Sanchez A, Mariano NA, Maldonado-Almanza B, Reyes-Gracia V. Factors affecting ethnobotanical knowledge in a mestizo community of the Sierra de Huautla Biosphere Reserve, Mexico. Journal of Ethnobiology and Ethnomedicine. 2014;10:1-19.

48. Weckmuller H, Barriocanal C, Maneja R, Boada M. Factors Affecting Traditional Medicinal Plant Knowledge of the Waorani, Ecuador. Sustainability. 2019;11:1-12.

49. Gouwakinnou NG, Lykke AM, Assogbadjo AE, Sinsin B. Local knowledge, pattern and diversity of use of Sclerocarya birrea. Journal of Ethnobiology and Ethnomedicine. 2011;7:1-9.

50. Fandohan B, Assogbadjo AE, Glèlè Kakaï RL, Kyndt T, De Caluwé E, Codjia CJ-T, et al. Women's Traditional Knowledge, Use Value, and the Contribution of Tamarind (Tamarindus indica L.) to Rural Households' Cash Income in Benin. Economic Botany. 2010;64:248-59.

51. Albuquerque UP, Hanazaki N. Five Problems in Current Ethnobotanical Research-and Some Suggestions for Strengthening Them. Hum Ecol. 2009;37:653-61.

52. Ackerman IL, Constantino R, Gauch, Jr HG, Lehmann J, Riha SJ, Fernandes ECM. Termite (Insecta: Isoptera) Species Composition in a Primary Rain Forest and Agroforests in Central Amazonia. Biotropica. 2009;41:226-33.

53. Agutu A, Imbo C, Makori O, Rotich RK. Impact of African Traditional Termite Control Methods on Conservation of Biodiversity: A Review. Journal of Biology, Agriculture and Healthcare. 2016;6:112-20.

54. Norman VC, Hoppé M, Hughes WOH. Old and wise but not size: factors affecting threat response behaviour and nestmate recognition in Acromyrmex echinatior leaf-cutting ants. Insectes Sociaux. 2014;61:289-96.

55. Running K, Burke J, Shipley K. Perceptions of Environmental Change and Climate Concern Among Idaho's Farmers. Society \& natural resources. Routledge; 2017;30:659-73.

56. Millennium Ecosystem Assessment. Ecosystem and Human Well-being: Wetlands and Water Synthesis. Washington, DC.: World Resources Institute; 2005.

\section{Figures}




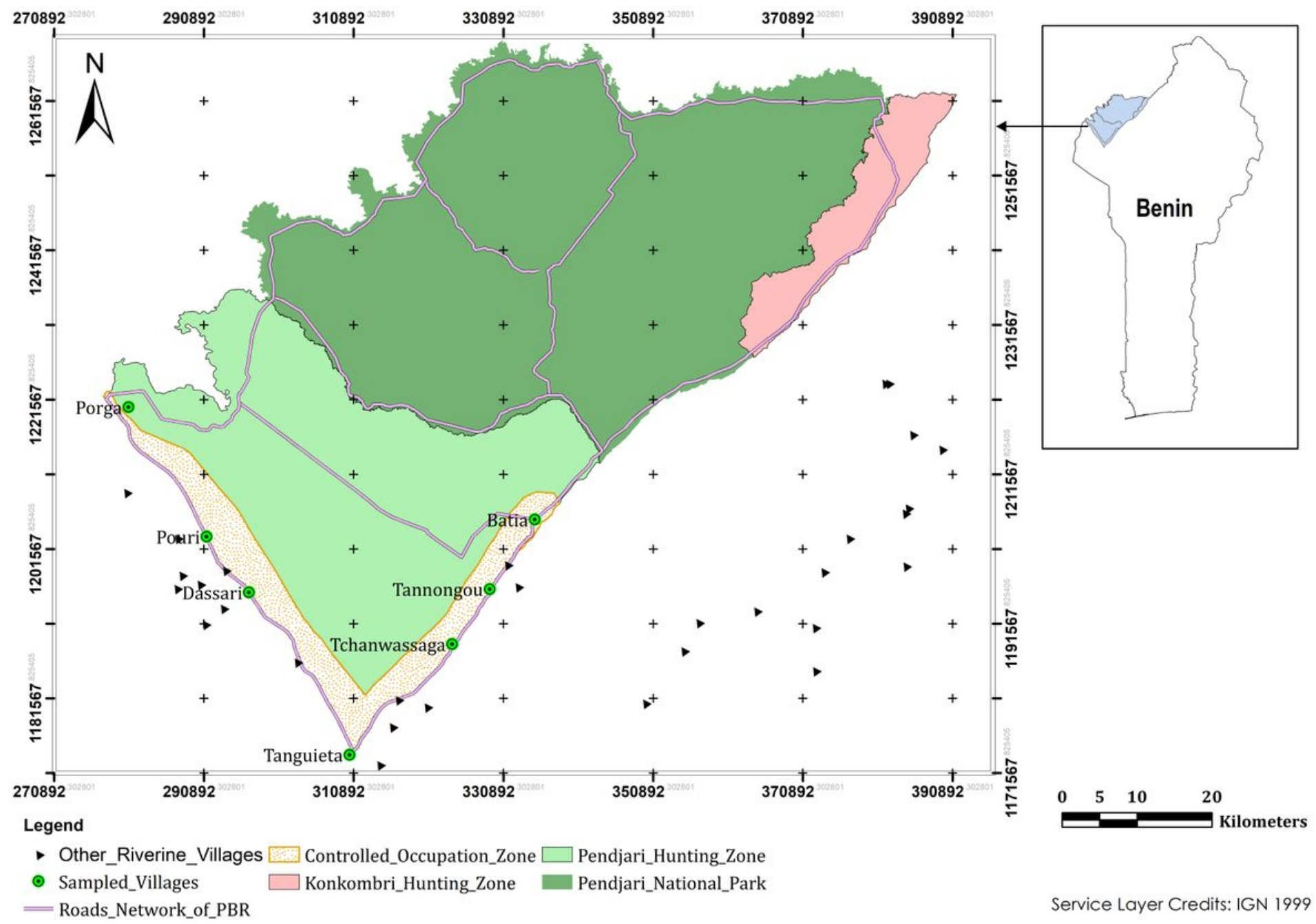

\section{Figure 1}

Map of Biosphere Reserve of Pendjari showing the sampled villages 


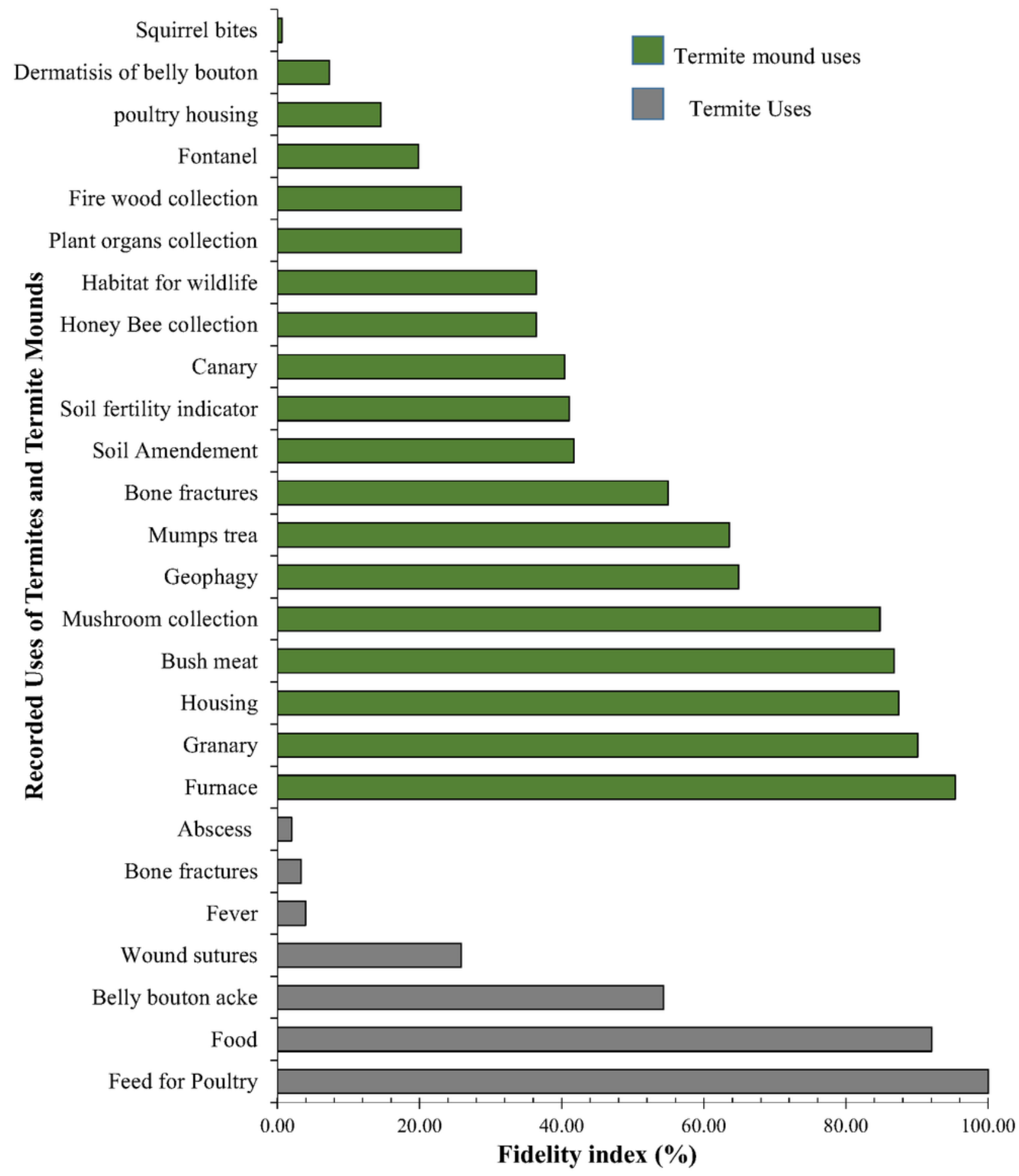

Figure 2

Cited usages per use-category and global importance of different use-types 

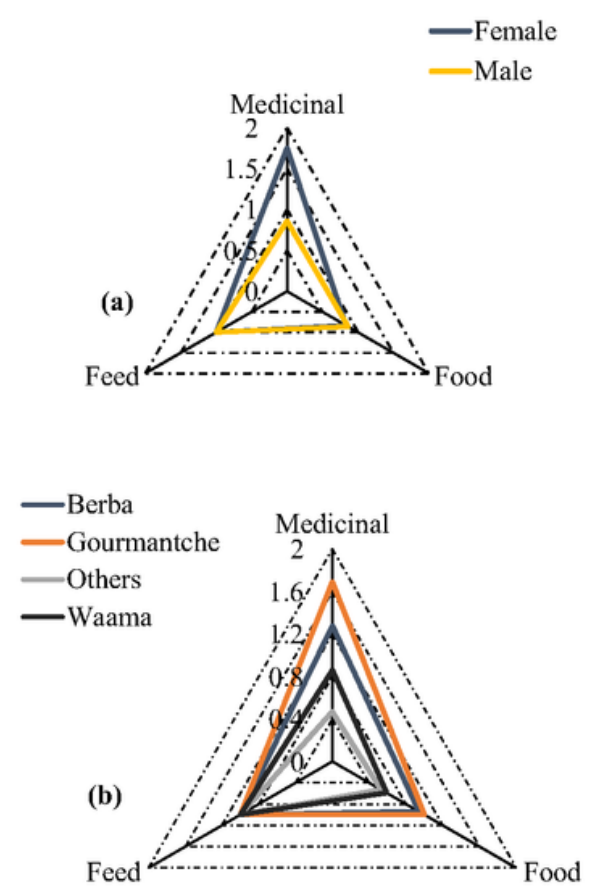
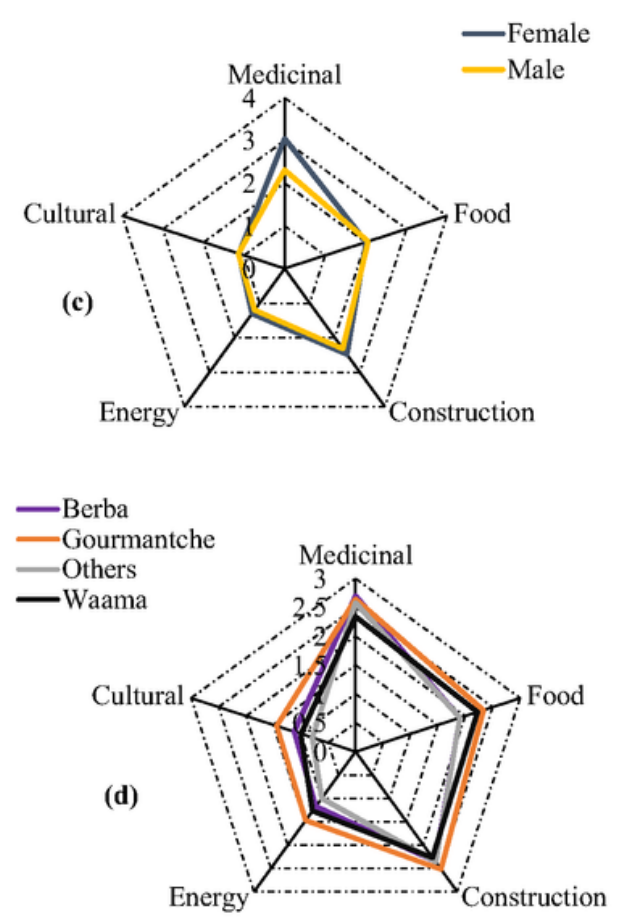
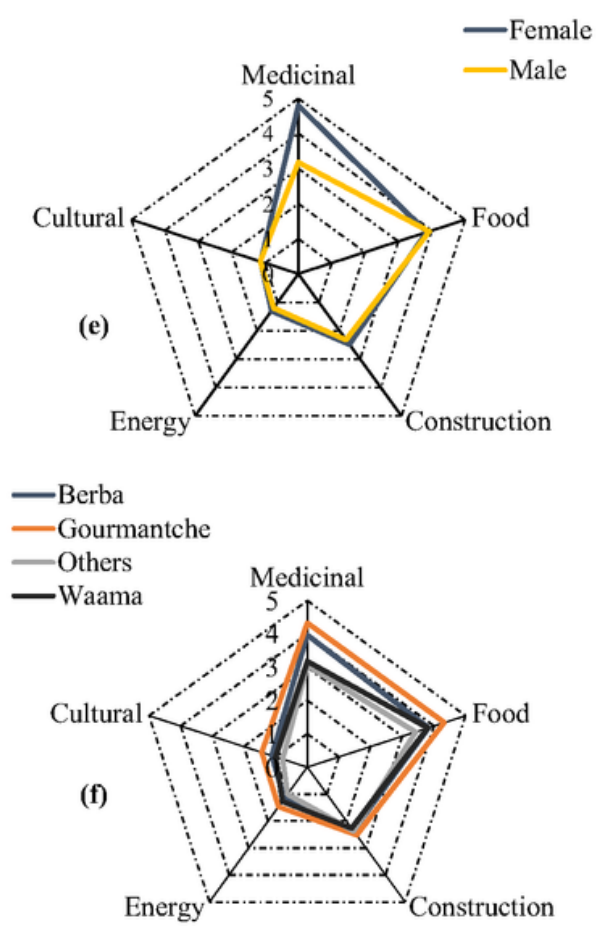

\section{Figure 3}

Variation of reported uses-value across termite, termite mound and overall use-categories following gender and ethnicity Legend: (a) - comparison of different recorded use-categories termite species following gender, (b)- comparison of different recorded use-categories of termite species following ethnicity, (c)- comparison of different recorded use-categories of termite mounds following gender, (d)comparison of different recorded use-categories of termite mounds following ethnicity, (e)-variation of recorded use-categories of termite and termite mounds following gender, and (f)- variation of recorded use-categories of termite and termite mounds following ethnicity. 

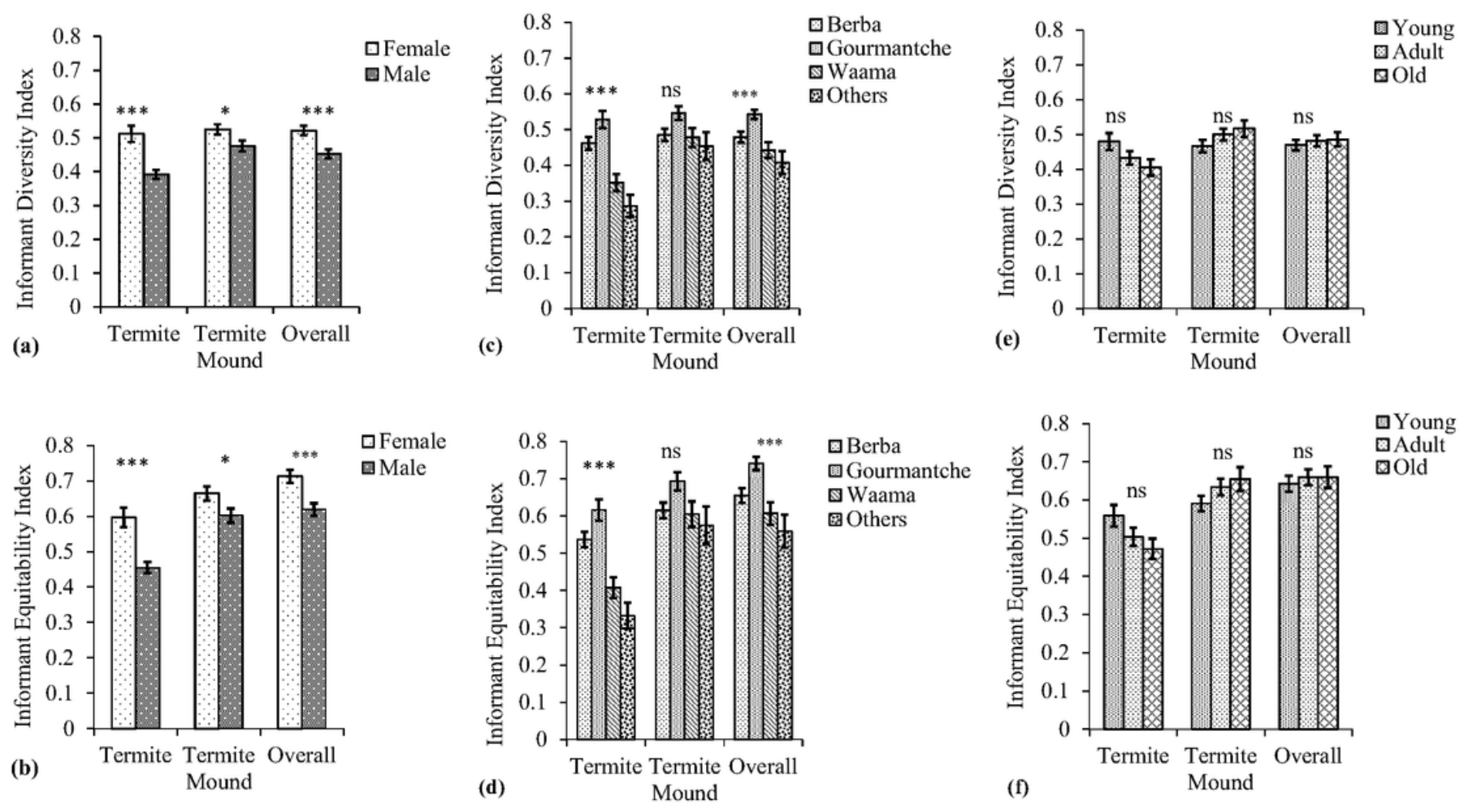

\section{Figure 4}

Influence of sociocultural factors on the use knowledge pattern of termites and their mounds around Pendjari Biosphere Reserve. Legend: (a) - comparison of the informant diversity index of the utilization knowledge of termite and termite mounds according to Informants' gender (Male and Female); (b) comparison of the equitability index of the utilization knowledge according to gender; (c)- comparison of the informant diversity index of the utilization knowledge of termite and termite mounds according to the ethnicity; (d)- comparison of the equitability index of the utilization knowledge of termite and termite mounds according to informants 'ethnicity; (e)-comparison of the informant diversity index of the utilization knowledge of termite and termite mounds according to class of ages (Old, Adult and Young); and $(f)$ - comparison of the equitability index of the utilization knowledge of termite and termite mounds according to class of ages (Old, Adult and Young); (ns): p-value $>0.05$ means there is no significant difference, $(*): 0.01<p$-value $<0.05$ means there is significant difference, $(* *): 0.001<p$-value $<0.01$ means there is high significant difference, $(* \star *)$ : $p$-value $<0.001$ means there is very high significant difference. 


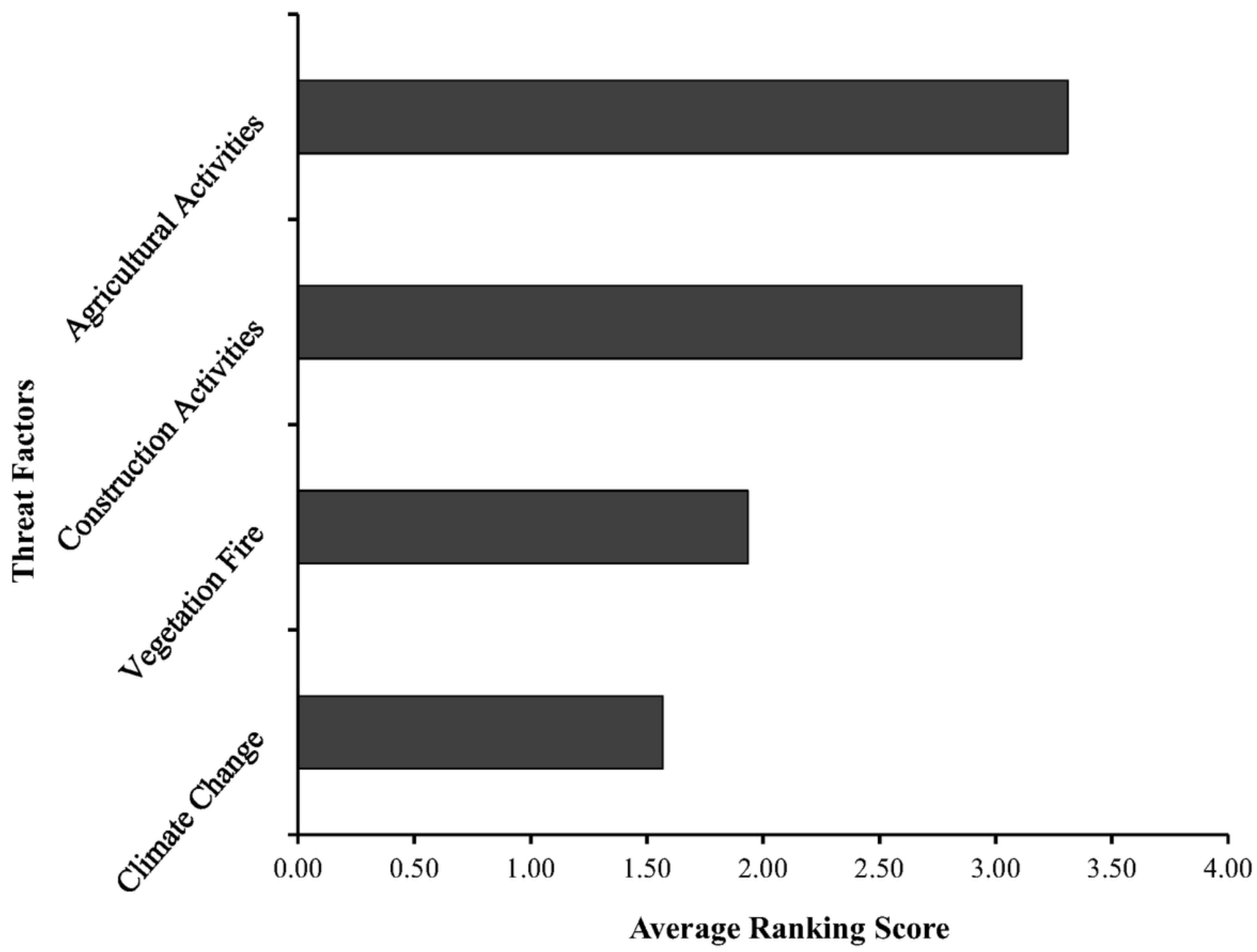

Figure 5

Importance of threat factors of termites and their mounds around PBR 


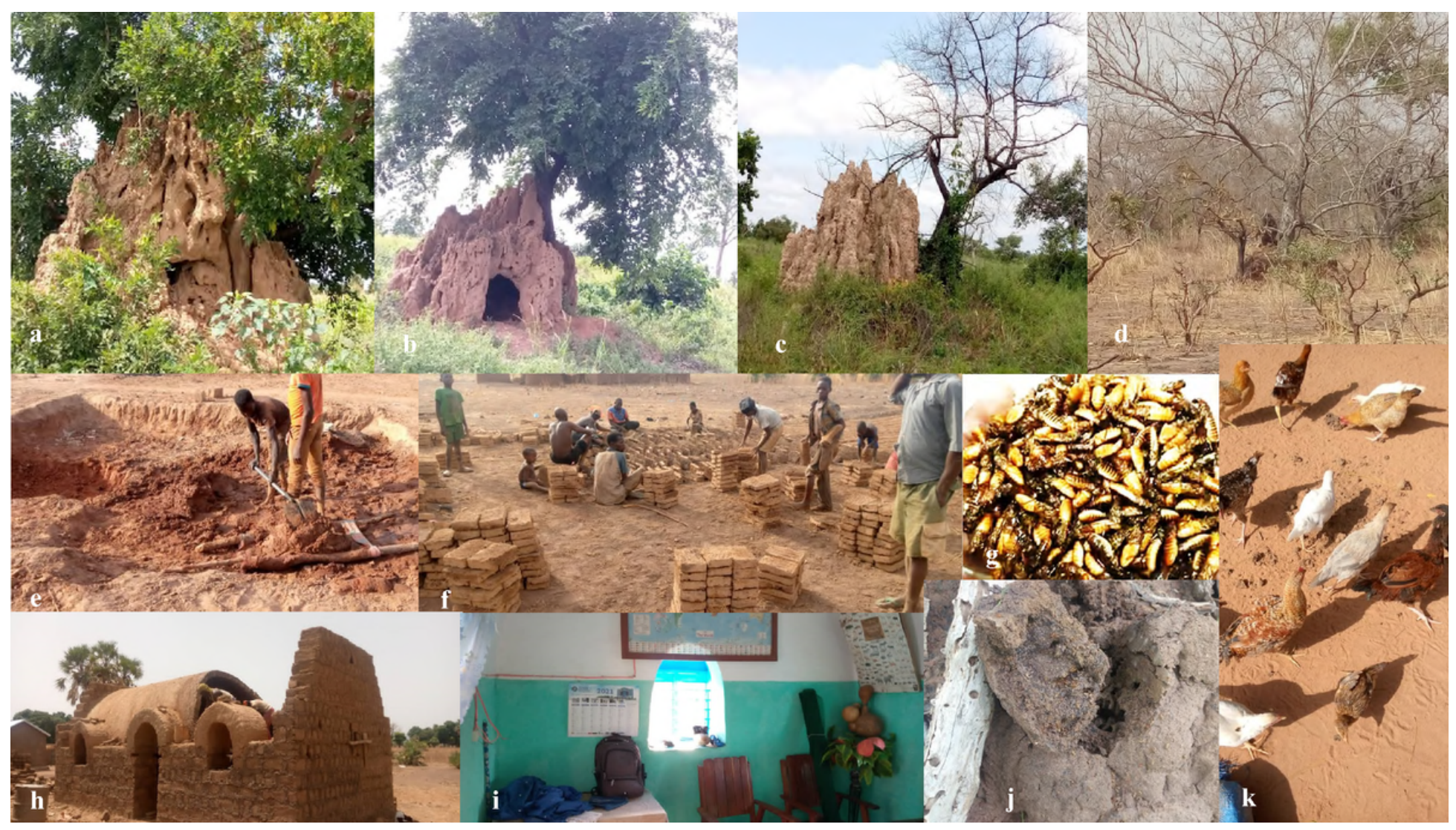

\section{Figure 6}

Some recorded use - types of termites and termite mounds around Pendjari Biosphere Reserve Legend: ( $a \& b)$ - termite mounds used as sites for collection of medicinal plant species, (c)-termite mounds used as sites for collection of firewood, (d)- termite mounds used as ecological niche by wildlife (Baboon), (e)destruction of dead termite mounds for construction purposes, (f)-fabrication of bricks based on termite mounds soil for voute nubienne construction, (g)- roasted wingless termites consumed by local people, (h)- example of voute nubienne (external view), (i)- example of voute nubienne (internal view), (j)collected termites specimen with their mounds destined for poultry feeding, and $(k)$ - poultry fed on termite species collected from the field.

\section{Supplementary Files}

This is a list of supplementary files associated with this preprint. Click to download.

- QUESTIONNAIRE.docX 